Харченко О.М., к. г. н., дои. Національний університет харчових технологій м. Київ, Україна

\title{
ПІДВИЩЕННЯ КВАЛІФІКАЦІЇ ПЕРСОНАЛУ В ІНДУСТРІӤІ ГОСТИННОСТІ
}

У сучасних умовах сфера гостинності потребує професійної підготовки співробітників, конкурентоспроможних на туристському ринку, компетентних, відповідальних, професіоналів у своєму виді діяльності й суміжних областях, готових до ефективної роботи в умовах застосування міжнародних стандартів, здатних до безперервного особистісного й професійного росту, соціальної й професійної мобільності, що прагнуть до безперервної освіти й здатних адаптуватися в постійно мінливому зовнішньому середовищі.

Підвищення кваліфікації персоналу - це навчання, яке направлене на підтримку і удосконалення професійного рівня, знань і умінь персоналу. Потреба організації в підвищенні кваліфікації іiї співробітників обумовлена: змінами зовнішнього і внутрішнього середовища, удосконаленням процесу управління, освоєнням нових видів і сфер діяльності [1].

На сьогодні у індустрії гостинності існує кілька підходів до процесу підвищення кваліфікації персоналу: інструментальний (безпосереднє задоволення потреб у підвищенні кваліфікації); особистісний (індивідуальне розглядання потреб кожного працівника); економічний (ефект від підвищення кваліфікації працівника, тощо).

Оцінка ефективності програм навчання персоналу є складовою управління підприємствіндустрії гостинності. Витрати на підвищення кваліфікації персоналу тісно пов'язані з підвищенням ефективності діяльності підприємства. У багатьох країнах світу витрати, які пов'язані з підвищенням професійного розвитку персоналу відносять до інвестицій. На жаль, в Україні статистика таких витрат невтішна, цей показник становить менше 1\% від фонду заробітної плати.

Згідно статистичних даних, найоптимальнішим строком для проходження співробітниками підвищення кваліфікації (повторного навчання на робочому місці) $35 \%$ вітчизняних керівників вважають період не менше одного разу на рік і $29 \%$ - не менше одного разу на півроку. 58\% респондентів вважають, що навчання повинно включати 
конкретні і практичні завдання за вузькою спеціалізацією, а 40\% - за необхідне проводити навчання згідно з посадовими вимогами [1].

Мотивація персоналу до вдосконалення професійної майстерності актуалізується:

- прагненням зберегти роботу, залишитись на займані посаді;

- бажанням отримати підвищення або зайняти нову посаду;

- матеріальним зацікавленням (підвищенням заробітної плати);

- зацікавленістю до самого процесу професійної підготовки;

- бажанням професійного спілкування;

- зміною обстановки.

Методи підвищення кваліфікації персоналу поділяються на дві групи:

1) навчання на робочому місці;

2) зовнішне навчання.

На робочому місці основними методами підвищення кваліфікації є: інструктаж, стажування, учнівство, наставництво, тощо.

Зовнішнє навчання передбачає лекції, ділові ігри, самостійну підготовку, семінари, тренінги та ін.

Одним із методів підвищення кваліфікації персоналу індустрії гостинності, які дозволяють розв'язувати важливі проблеми підготовки кадрів $є$ тренінги. Вони передбачають відпрацювання певних навичок у поєднанні з підсиленням мотивації до вдосконалення своєї роботи.

Тренінги поділяються на комунікативні (психологічні) і спеціалізовані. Комунікативні - надають навички спілкування з гостями; техніки ведення переговорів, презентацій, виступів, ділового спілкування; методів вирішення конфліктів.

При виборі методів підвищення кваліфікації персоналу в індустpiї гостинності варто враховувати принципи актуальності, участі, повторення та зворотного зв'язку.

Слід зазначити, що підвищення кваліфікації персоналу індустрії гостинності безперервний процес, що сприяє саморозвитку, підготовці до більш відповідальної роботи. Крім того, досягнуті результати приносять моральне задоволення.

\section{Список бібліографічних посилань}

1. Крушельницька О.В. Управління персоналом : навч. посіб. / О.В. Крушельницька, Д.П. Мельничук. - Київ : Кондор, 2005. - 308 с. 